\title{
PENGGUNAAN GOOGLE REVIEW SEBAGAI PENILAIAN KEPUASAN PENGUNJUNG DALAM PARIWISATA
}

\author{
Fathia Uqimul Haq, Heryadi Rachmat \\ Sekolah Pascasarja, Universitas Padjadjaran, Jalan Dipatiukur no.53 Kecamatan Coblong Kota Bandung \\ E-mail: fathiauqimul@gmail.com, heryadirachmat202@gmail.com
}

\begin{abstract}
ABSTRAK
Google review merupakan salah satu dari fitur Google maps. Fitur sederhana yang mampu berdampak besar ini digunakan untuk memberi nilai angka dan ulasan berupa teks dan foto pada sebuah tempat. Di era big data ini, pengguna dengan mudah memberikan nilai sesuai dengan faktor-faktor kepuasan pengunjung. Tujuan penelitian ini untuk mengetahui bagaimana google review menjadi fitur untuk menilai kepuasan pengunjung dalam pariwisata. Metode penelitian menggunakan kajian literatur yang diambil dari jurnal, pustaka, dan media massa. Temuan dari penelitian ini google review dapat dimanfaatkan sebagai sarana evaluasi dini dalam sebuah sektor bisnis pariwisata untuk meningkatkan pelayanan daring. Diharapkan bisnis pariwisata saat ini bukan hanya memberikan pelayanan produk nyata saat pengunjung datang, tetapi mampu melayani melalui daring untuk membangun reputasi baik di hadapan warganet atau calon pengunjung.
\end{abstract}

Kata kunci; Google review, kepuasan pengunjung, pariwisata.

\section{THE USE OF GOOGLE REVIEW AS ASSESMENT OF VISITORS SATISFACTION IN TOURISM}

\section{ABSTRACT}

Google Reviews is one of Google maps features. This simple impactful feature is used to give numbers and reviews in a text and photos in a place. In this big data era, users easily provide value according to visitor satisfaction factors. The purpose of this research is to find out how Google reviews become a feature to assess visitor satisfaction in tourism. Research methods use literature studies taken from journals, libraries, and mass media. Findings from this research Google Review can be utilized as an early evaluation tool in a tourism business sector to improve online services. It is hoped that tourism businesses nowadays not only provide real product service when visitors come, but also are able to serve through online to build a good reputation in the presence of netizen or prospective visitors.

Key words; Google review, visitor's satisfaction, tourism.

\section{PENDAHULUAN}

Google Review menjadi salah satu fitur yang dibuat oleh Google untuk seluruh alamat yang tercantum dalam peta Google. Biasanya google review muncul pada saat pengguna mencari sebuah tempat atau setelah seseorang mengunjungi suatu tempat. Misalnya, saat seseorang mengunjungi sebuah restoran, tanpa disadari setelah ia pulang maka akan terdapat pemberitahuan dalam layar ponselnya untuk mengulas restoran tersebut.

Google review juga bisa dilihat saat pengguna mencari sebuah tempat. Ketika seseorang mencari destinasi yang dituju, ulasan dalam berbentuk bintang dan ulasan kata akan muncul. Di sana kita dapat melihat sejauh mana orang-orang yang berkunjung ke destinasi tersebut puas terhadap apa yang dilayani.

Dalam bidang pariwisata, google review menjadi salah satu aspek penting dalam era big data untuk mengumpulkan jejak-jejak wisatawan ke suatu tempat. Pasalnya, tanpa disadari, melalui fitur lokasi ponsel yang terus menyala dan kita bawa kemanapun akan memberikan pemberitahuan otomatis dalam telepon genggam. Google review menyuruh kita untuk mengulas tempat yang baru saja dikunjungi. Buruknya, meskipun kita tidak benar-benar mengunjungi tempat tersebut, seperti hanya melewati tempatnya saja, biasanya google review akan memberikan pemberitahuan langsung untuk mengulasnya.

Era big data ini menghimpun banyak data melalui jejak lokasi dari setiap ponsel. Seperti siapa dan bagaimana pribadinya, kebiasaan dalam memutuskan kunjungan, atau tempat yang sering dikunjungi. Tak dapat dipungkiri, hal ini menjadi dampak positif yang besar bagi bisnis pariwisata. Bagaimana sektor ini mampu memilah dan menyesuaikan destinasinya seperti yang diharapkan pengunjung dan sesuai dengan segmentasi.

Dewasa ini, penggunaan google review ini juga diperhatikan oleh beberapa sektor bisnis pariwisata baik dalam bidang kuliner atau tempat hiburan. Profesi admin media sosial menjadi diburu saat ini untuk mengoperasikan platform daring dari setiap destinasi. Pasalnya, saat ini pengunjung akan melihat sesuatu dari internet baik dari google review atau 
media sosial atau yang disebut electronic-word of mouth (eWom).

eWom berpengaruh terhadap keputusan berkunjung wisatawan terhadap sebuah destinasi. Seperti pada penelitian eWom destinasi Hawai Waterpark Malang yang mempengaruhi minat berkunjung lantaran adanya ulasan melalui informasi yang diberikan wisatawan lain. Mulai dari foto, video, dan ulasan berupa kalimat. Kepercayaan ini menjadi salah satu hal penting dalam era big data untuk memberikan keputusan berkunjung kepada wisatawan lain (Widyanto, Sunarti, \& Pangestuti, 2017).

Google review menjadi sebuah tantangan besar bagi sektor bisnis pariwisata. Karena namanya akan mencuat dan dilihat oleh ratusan hingga jutaan pengguna yang hendak mencari sebuah destinasi. Belum lagi para pengguna yang tidak sengaja mendapat pemberitahuan adanya sebuah tempat di daerah dimana ia tengah berada.

Penelitian ini bertujuan untuk melihat pentingnya Google review sebagai penilaian kepuasan pengunjung di sektor pariwisata. Bagaimana pengguna memberikan usaha lebih untuk mengulas sebuah tempat dengan memberikan bintang, ulasan seperti kritik dan saran, pujian, dan foto.

\section{METODE}

Penelitian ini menggunakan metode studi literatur di mana penulis membaca, mencatat, dan mengolah bahan dari sumber pustaka, media massa, dan penelitian terkini. Metode ini pun membantu menemukan pemecahan masalah dari hal yang ditemukan di lapangan.

\section{HASIL DAN PEMBAHASAN}

Google review merupakan salah satu fitur dalam Google Maps yang dikembangkan oleh Google untuk memberikan pemeringkatan dan ulasan. Pengguna yang telah menaruh alamat dengan rincian yang pasti khususnya dalam bisnis biasanya akan mendapatkan ulasan dari pengguna. Google review merupakan salah satu hal dari era big data saat ini di mana setiap orang dapat menaruh jejak setelah mereka mendatangi sebuah tempat.

Fitur ulasan daring menjadi sangan penting bagi dunia bisnis khususnya di sektor pariwisata. Pasalnya, selain memudahkan wisatawan untuk mengunjungi lokasi destinasi, mereka pun dapat mengetahui seberapa besar pemeringkatan yang diberikan oleh wisatawan yang pernah datang. Apalagi dengan tambahan fitur ulasan dan tambahan foto menambah validasi ulasan dari pengalaman wisatawan.
Ulasan daring juga menumbuhkan tren yang didapat dari internet. Tren google diraih melalui banyaknya pengguna yang mencari sesuatu di laman pencari googlenya. Ulasan daring menjadi salah satu pendukung tren google yang tersedia di laman Google. Lewat tren Google, banyak hal yang dapat dilakukan seperti memprediksikan perilaku pariwisata juga apa yang sering dicari oleh pengguna (Gawlik, Karbaria, \& Kaur, 2011).

Selain berupa pemberian nilai 1-5 yang akan dikemas dalam bintang, Google review juga memiliki ulasan berupa kalimat dan foto yang dapat dibagikan gratis dari pengunjung. Hal ini menjadi penting lantaran sebuah destinasi memiliki reputasi daring yang dapat dilihat kapan saja dan di mana saja.

Google review hadir sebagai salah satu platform di era big data yang yang menjadi sumber data dari pengguna. Dalam bidang pariwisata, google review termasuk dalam UGC data yakni pengguna atau manusia yang mengoperasikan teknologi hingga membuat data itu sendiri berupa data tekstual daring dan data foto daring; data alat, termasuk data GPS, mobile roaming data, Bluetooth data seperti transaksi data situs, laman situs, data pemesanan daring, dan lain-lain (Li, Xu, \& Tang, 2018).

Kepuasan pengunjung dapat dilihat dari beberapa kriteria. Lupiyoadi dalam Rosita, Marhanah, \& Wahadi (2016) menjelaskan kepuasan pelanggan dilihat dari kualitas produk, kualitas pelayanan, emosional, harga, dan biaya.

Kepuasan pelanggan menjadi poin dimana seseorang mengulas sebuah tempat. Mulai dari kualitas produk yang diberikan untuk memenuhi kebutuhan wisatawan. Seperti makanan yang sesuai dengan selera, suasana yang menyenangkan, serta fasilitas yang memadai.

Kualitas pelayanan juga dapat menjadi faktor seseorang mengulas sebuah tempat. Seperti pelayanan mulai dari pembayaran tiket jika masuk ke sebuah destinasi wisata, penyediaan tempat parkir, Tourist Information Center (TIC), dan lain-lain.

Emosional juga menjadi faktor penting dalam menentukan baik buruknya sebuah ulasan dan pemeringkatan. Ketika seseorang melihat suatu destinasi sesuai ekspektasinya, emosional berpengaruh terhadap perjalanannya saat itu. Emosional juga bergantung kepada pelayanan yang diberikan sehingga wisatawan mau dan mampu mengulas sebuah tempat.

Harga dan biaya adalah faktor penting dalam penentuan sebuah destinasi. Hal ini juga berpengaruh kepada ulasan yang akan diberikan kepada sebuah tempat. Jika harga dapat membuat wisatawan senang, maka ulasan pun akan baik. Harga murah belum tentu 
menjamin ulasan baik jika kualitas produk, pelayanan, dan emosional tidak mendukung.

Google review juga menjadi salah satu produk Smart Tourism. Tujuan utama dalam destinasi smart tourism adalah menciptakan pengalaman yang pintar, yang didefinisikan sebagai sebuah pengalaman yang dimediasi oleh teknologi dan ditingkatkan melalui personalisasi, contex awareness, dan real time monitoring (Vecchio, Mele, \& Ndou, 2017).

Melalui ratusan ribu ulasan dari setiap tempat khususnya pariwisata mampu menggambarkan keadaan sebuah tempat. Juga menciptakan ruang baru dalam era big data yang bias mengklasifikasikan produk dan pengalaman manusia lewat konten yang disediakan pengguna.

Ulasan yang terangkum dalam satu fitur Google Maps yang terangkum Google review ini menjadi evaluasi sederhana yang tidak membutuhkan komputasi rumit. Pemanfaatan ini dapat berpengaruh baik dalam bidang pariwisata untuk meningkatkan kepuasan pengunjung. Seperti halnya Google Trend yang dimanfaatkan sebagai big data yang sederhana dalam mengevaluasi atau inovasi dalam pariwisata (Purnaningrum \& Ariqoh, 2019).

Demikian Google review yang khusus dibuat untuk dimanfaatkan di bidang pariwisata secara singkat menilai kepuasan pengunjung.

\section{SIMPULAN}

Google review merupakan salah satu fitur dari Google maps yang dapat dimanfaatkan sebagai evaluasi dini dari sebuah destinasi pariwisata. Bisnis dalam sektor pariwisata kini dengan mudah memanfaatkan ruang ini sebagai upaya meningkatkan pelayanan. Penilaian konsumen kini tidak lagi secara manual. Namun di era big data, dimana data hadir dari setiap pengguna, dapat dimanfaatkan secara gratis dan sebagai alat untuk membangun citra dan reputasi sebuah destinasi. Diharapkan, bisnis pariwisata kini mampu melayani bukan hanya dari segi pelayanan kualitas secara produk, tetapi dari pelayanan daring mulai dari google maps, google review, dan media sosial.

\section{DAFTAR PUSTAKA}

Gawlik, E., Karbaria, H., \& Kaur, S. (2011, Desember 15). Article. Diambil kembali dari Research Gate: https://www.researchgate.net/profile/Hardik _Kabaria/publication/265201229_Predicting _tourism_trends_with_Google_Insights/link s/54e4a5b00cf276cec171d803/Predictingtourism-trends-with-Google-Insights.pdf

Li, J., Xu, L., \& Tang, L. (2018, April 10). Big Data in Tourism Research : a literature review. Tourism Management(68), 301-323.

Purnaningrum, E., \& Ariqoh, I. (2019, Desember). Google Trends Analytics dalam Bidang Pariwisata. Majalah Ekonomi, XXIV(2), 232243.

Rosita, Marhanah, S., \& Wahadi, W. H. (2016). Pengaruh Fasilitas Wisata dan Kualitas Pelayanan Terhadap Kepuasan Pengunjung di Taman Margasatwa Ragunan Jakarta. Jurnal Manajemen Resort dan Leisure, 13(1), 61-72.

Vecchio, P. D., Mele, G., \& Ndou, V. (2017, November 01). Creating Value from Social Big Data : Implications for Smart Tourism Destinations. Information Processing and Management(54), 847-860.

Widyanto, A., Sunarti, \& Pangestuti, E. (2017). Pengaruh E-WOM di Instagram Terhadap Minat Berkunjung dan Dampaknya Pada Keputusan Berkunjung (Survei Pada Pengunjung Hawai Waterpark Malang). Jurnal Administrasi Bisnis, 45(1), 94-101. 